\title{
OCCUPATIONAL RISK FACTORS FOR DEMENTIA IN A SAMPLE OF OLDER ADULTS COVERED BY THE IRANIAN OIL INDUSTRIES' HEALTH CENTERS, 2018
}

\author{
Hossein Ghassemzadeh ${ }^{1}$ \\ Ahmadali Akbari Kamrani ${ }^{2}$ \\ Yadollah Abolfathi Momtaz ${ }^{3}$ \\ Mehdi Rassafiani $^{4}$ \\ Fatemeh Nourhashemi ${ }^{5}$ \\ Robab Sahaf ${ }^{6}$ \\ Salman Naderian ${ }^{7}$
}

\begin{abstract}
Introduction: here is a new case of dementia in the world every three seconds. It kills more people in the US than breast cancer and prostate cancer combined, while it is the number one killer in England and Wales. The current cost of the disease is about a trillion US dollars a year, and that is forecast to double by 2030.Object: The aim of this study was to determine the probable
\end{abstract}

occupational and environmental risk factors of dementia among the retirees of Iranian oil industries. Methods: A casecontrol study of 551 randomly selected older adults, all aged 60 and above including 180 demented and 371 nondemented retirees, pair matched for education and gender, was conducted. We evaluated the adjusted associations between dementia risk and the probable

\footnotetext{
${ }^{1}$ Department of Ageing, The University of Social Welfare and rehabilitation Sciences, Tehran, Iran

${ }^{2}$ Professor of Department of Ageing, Research Center on Ageing, the University of Social Welfare and Rehabilitation Sciences, Tehran, Iran The corresponding author

${ }^{3}$ Associae Professor of Department of Ageing, Research Center on Ageing, the University of Social Welfare and Rehabilitation Sciences, Tehran, Iran

${ }^{4}$ Associate Professor, Occupational Therapy Department, Faculty of Allied Health Sciences, Kuwait University, Kuwait

${ }^{5}$ Professeur Fati Nourhashemi MD, PhD, Chef de pôle Médecine Gériatrie Gérontopôle CHU Toulouse, France

${ }^{6}$ Professor of Department of Ageing, Research Center on Ageing, the University of Social Welfare and Rehabilitation Sciences, Tehran, Iran The corresponding author

${ }^{7}$ Department of Ageing, The University of Social Welfare and rehabilitation Sciences, Tehran, Iran
} 


\section{Periódico do Núcleo de Estudos e Pesquisas sobre Gênero e Direito \\ Centro de Ciências Jurídicas - Universidade Federal da Paraíba \\ V. 8 - No 04 - Ano 2019 - Special Edition}

ISSN | 2179-7137 | http://periodicos.ufpb.br/ojs2/index.php/ged/index

occupational and environmental families, the healthcare system, and the variables through multiple logistic regression.Results: A history of economy. In the United States, Alzheimer's disease (AD) is a leading exposure to air pollution (Adjusted $\mathrm{OR}=2.00,95 \% \mathrm{CI}=1.00-7.00)$, head injuries (Adjusted $\mathrm{OR}=2.00,95 \% \mathrm{CI}=$ 1.00-6.00) and more than 20 years of work in the operational fields (Adjusted $\mathrm{OR}=5.00, \quad 95 \% \mathrm{CI}=3.00-8.00)$ was significantly correlated with an increased risk of dementia. We could not find any significant associations between dementia risk and exposure to fossil fuels, solvents, noise pollution and or a combination of occupational risk factors. Conclusion: The results propose that long-term exposure to field occupational risk factors is likely to increase the risk of dementia. We suggest simultaneous serial oil industries' particulate evaluations with proper cognitive assessments for the pre-retired staff.

KeyWords: Dementia, Occupational risk factors, Case-control, Oil industry

\section{Introduction}

Today, there are nearly 50 million demented people living in the Major Neurocognitive disorders (dementias) have tremendous consequences for individuals, their world and it is believed that the figure will have tripled in 30 years(2). It has been proposed that a noticeable rise in 


\section{Periódico do Núcleo de Estudos e Pesquisas sobre Gênero e Direito \\ Centro de Ciências Jurídicas - Universidade Federal da Paraíba \\ V. 8 - No 04 - Ano 2019 - Special Edition}

ISSN | 2179-7137 | http://periodicos.ufpb.br/ojs2/index.php/ged/index

life expectancy and subsequent global population aging have been the main causes for this phenomenon. Right now, the global expected annual cost of caring for dementia patients has surpassed $\$ 1$ trillion(3). The intolerable financial burden of care for dementia patients and the unavailability of an effective treatment for postponing or stopping dementia progression has made it one of the most horrific diseases for the nations and families(4), while pharmaceutical advances for the disease have not been satisfying(3). Furthermore, until now, we have not completely comprehended the causes and etiologies of the disease, which make it more urgent to put dementia under microscope. In order to cope with worldwide difficulties caused by dementia, taking primary preventive measures such as adjusting modifiable risk factors like high blood pressure, obesity, diabetes, sedentary life style and smoking have been shown to be effective(5). For example, a considerable drop in the number of Alzheimer's disease' rates in some countries has been attributed to an effective modulating of the preventable risk factors(6). However, in the absence of modifiable risk factors, it becomes highly challenging to explain the possible risk factors responsible for the onset of the disease. To date, there are numerous studies reporting on various risk factors for dementia (7-21). To our knowledge, given the geographical differences in dementia prevalence and incidence, there is no comprehensive domestic study evaluating possible occupational risk factors for dementia in the Iranian population. Given the considerable differences between the culture and life styles of the Iranian population and other parts of the World, validating the findings from other parts of the World to the Iranian population is a highly demanding task. We performed a casecontrol study in a sample of older adults covered by $\mathrm{NIOC}^{8}$ health centers. Our aim was to provide an overview of the possible occupational risk factors associated with prevalent dementia in this group.

\footnotetext{
${ }^{8}$ National Iranian Oil Company
} 
Table 1. Functional limitations associated with impairment in different cognitive domains

\section{Cognitive domain}

Complex attention

\section{Examples of changes in everyday activities}

Normal tasks take longer, especially when there are competing stimuli; easily distracted; tasks need to be simplified; difficulty holding information in mind to do mental calculations or dial a phone number

Executive functioning Difficulty with multi-stage tasks, planning, organizing, multitasking, following directions, keeping up with shifting conversations

Learning and memory Difficulty recalling recent events, repeating self, misplacing objects, losing track of actions already performed, increasing reliance on lists, reminders

Language Word-finding difficulty, use of general phrases or wrong words, grammatical errors, difficulty with comprehension of others' language or written material

PerceptualGetting lost in familiar places, more use of notes and maps,

motor/visuospatial function

Social cognition
Disinhibition or apathy, loss of empathy, inappropriate behavior, loss of judgment

\section{Materials and methods}

551 individuals aged 60 and above, including 180 cases with confirmed dementia diagnosis based on DSM-5 criteria (table 2) (1), have participated in this study. The typical diagnosed cases included when acquired cognitive impairment has become severe enough to compromise social and/or occupational functioning (22), abnormal MMSE (mini-mental state examination) score along with indicating changes in MRI/CT imaging and paraclinical records archived in the central medical 
data bases of the NIOC hospitals and oilfields in 2017. Cases were from 15 operational (provinces) across the NIOC health branches throughout the country who were compared with 371 elderly controls without dementia, matched for sex and educational level but not for age. The control group was selected using randomized multi-stage sampling from the same source of demographic data proportional to the population size of each province. The controls underwent a comprehensive medical and cognitive assessment, with no evidence of cognitive impairment, and were visited by a physician in the same period as the cases were visited. In the control group, we used a standard Farsi validated version of $\operatorname{MMSE}(23)$, a 30-point questionnaire that is used extensively in the clinical and research settings to measure cognitive impairment as a classification tool to stratify the patients into three subgroups of dementia based on the severity, namely mild dementia (20-22), moderate dementia (10-19), and severe dementia $(<9)$. A cutoff point of 19 for illiterates and low educated individuals, 27 for individuals having a moderate educational attainment and 29 for whom having academic educational attainment to separate the individuals suspected to having a cognitive problem was used. The proxies signed the consent forms since the dementia patients lack decision-making capacity. The participation rates for the cases and controls were $100 \%$ and $87 \%$, respectively.

\section{Table 2, Neurocognitive Disorders as Diagnosed in DSM-5}

\section{Diagnostic Major Neurocognitive}

Criteria Disorder/Dementia

A
Significant cognitive decline in one or more cognitive domains, based on:

1. Concern about significant decline, expressed by individual or reliable

\section{Minor Neurocognitive}

\section{Disorder/Dementia}

Modest cognitive decline in one or more cognitive domains, based on:

1. Concern about mild decline, expressed by individual or reliable informant, or observed by clinician. 
Diagnostic Major Neurocognitive

\section{Criteria Disorder/Dementia}

informant, or observed by

clinician.

2. Substantial impairment, documented by objective cognitive assessment.

B

Interference with independence in everyday activities.

\section{Minor Neurocognitive}

\section{Disorder/Dementia}

2. Modest impairment, documented by objective cognitive assessment.

No interference with independence in everyday activities, although these activities may require more time and effort, accommodation, or compensatory strategies

C Not exclusively during delirium.

D Not better explained by another mental disorder.

E Specify one or more etiologic subtypes, "due to"

Alzheimer's disease

Cerebrovascular disease (Vascular Neurocognitive Disorder)

Frontotemporal Lobar Degeneration (Frontotemporal Neurocognitive

Disorder)

Dementia with Lewy Bodies (Neurocognitive Disorder with Lewy Bodies)

Parkinson's disease

Huntington's disease

Traumatic Brain Injury

HIV Infection

Prion Disease

Another medical condition

Multiple etiologies

Adapted from: American Psychiatric Association: Diagnostic and Statistical Manual of Mental Disorders, Fifth Edition. Arlington, VA, American Psychiatric Association; 
Periódico do Núcleo de Estudos e Pesquisas sobre Gênero e Direito Centro de Ciências Jurídicas - Universidade Federal da Paraíba

V. 8 - No 04 - Ano 2019 - Special Edition ISSN | 2179-7137 | http://periodicos.ufpb.br/ojs2/index.php/ged/index

checklist.

the 3

\begin{tabular}{llll}
\hline $\begin{array}{l}\text { 3. Characteristics of the cases } \\
\text { and the controldemographic } \\
\text { characteristics }\end{array}$ & $\begin{array}{l}\text { Cases } \\
(\boldsymbol{\%})\end{array}$ & $\begin{array}{l}\text { Controls } \\
(\boldsymbol{\%})\end{array}$ \\
\hline age & $60-64$ & $59(32 \%)$ & $299(80 \%)$ \\
& & & \\
\cline { 2 - 4 } & & & \\
& $75-89$ & $100(55 \%)$ & $70(18 \%)$ \\
& & & \\
\cline { 2 - 4 } & $90+$ & $21(11 \%)$ & $2(0 / 3 \%)$ \\
\hline Sex & & $95(52 \%)$ & $207(55 \%)$ \\
& & & \\
& & &
\end{tabular}

\begin{tabular}{llll}
\cline { 2 - 3 } & female & $85(47 \%)$ & $164(44 \%)$ \\
\hline Education & Illiterate & $27(15 \%)$ & $22(5 \%)$
\end{tabular}

Elementary and 58(32\%) 53(14\%)

high elementary

Highschool or $\quad 68(37 \%) \quad 139(37 \%)$

diploma

\begin{tabular}{lll}
\hline $\begin{array}{l}\text { Associate and } \\
\text { bachelor's }\end{array}$ & 21(11\%) & $35(36 \%)$ \\
& & \\
\hline $\begin{array}{l}\text { Master's and } \\
\text { higher }\end{array}$ & $6(3 \%)$ & $22(5 \%)$
\end{tabular}


The univariate logistic regression showed that the risk of dementia was affected by occupational exposures to fossil fuels, solvents, unusual air and noise pollution, electromagnetic fields, a combination of occupational risk factors, recurring occupational head injury and a history of more than 20 years of working in the operational fields.

All data gathered from the recorded occupational health files, stated by the participants and reliable informants/proxies in the cases' setting4

\section{Logistic regression model results for dementia}

\begin{tabular}{|c|c|c|c|c|c|c|}
\hline \multirow[t]{9}{*}{$\begin{array}{l}\text { Occupational } \\
\text { risk factors }\end{array}$} & & Cases & Controls & $\begin{array}{l}\text { Unadjusted } \\
\text { Odds }\end{array}$ & $95 \% \mathrm{CI}$ & $\begin{array}{c}\text { p- } \\
\text { value }\end{array}$ \\
\hline & Fossil fuels & $19(10 \%)$ & $12(3 \%)$ & 2.00 & $\begin{array}{l}(1.00- \\
6.00)\end{array}$ & .018 \\
\hline & solvents & $8(4 \%)$ & $10(2 \%)$ & 1.00 & $\begin{array}{l}(0.00- \\
4.088)\end{array}$ & $<.001$ \\
\hline & $\begin{array}{l}\text { Electro-magnetic } \\
\text { fields }\end{array}$ & $12(6 \%)$ & $36(9 \%)$ & 1.046 & $\begin{array}{l}(0.00- \\
2.00)\end{array}$ & $<.001$ \\
\hline & Air pollution & $24(13 \%)$ & $14(3 \%)$ & 6.00 & $\begin{array}{l}(2.00- \\
12.00)\end{array}$ & $<.001$ \\
\hline & Noise pollution & $25(13 \%)$ & $64(17 \%)$ & 1.00 & $\begin{array}{l}(0.00- \\
2.00)\end{array}$ & $<.001$ \\
\hline & $\begin{array}{l}\text { A combination of } \\
\text { the Occupational } \\
\text { risk factors }\end{array}$ & $10(5 \%)$ & $9(2 \%)$ & 3.00 & $\begin{array}{l}(1.00- \\
10.018)\end{array}$ & .009 \\
\hline & Head trauma & $34(18 \%)$ & $16(4 \%)$ & 4.00 & $\begin{array}{l}(2.00- \\
9.00)\end{array}$ & $<.001$ \\
\hline & $\begin{array}{l}\text { Less than } 20 \\
\text { years of work in } \\
\text { the operational } \\
\text { fields }\end{array}$ & $20(11 \%)$ & $44(11 \%)$ & 1.00 & $\begin{array}{l}(0.00- \\
2.00)\end{array}$ & $<.001$ \\
\hline
\end{tabular}




\begin{tabular}{|l|l|l|l|l|l|l|}
\hline & $\begin{array}{l}\text { 20 years or } \\
\text { more of work in } \\
\text { the operational } \\
\text { fields }\end{array}$ & $47(26 \%)$ & $41(11.1 \%)$ & 2.000 & $(1.00-$ & $<.001$ \\
\hline
\end{tabular}

After adjusting for sex, and education, the results showed that the risk of developing dementia was significantly affected by an exposure to air pollution, traumatic brain injury and a history of more than 20 years of work in the operational fields. Indeed, a history of exposure to unusual air pollution was associated with a 2times increase in the risk of dementia $(\mathrm{OR}=2.00,95 \% \mathrm{CI}=1.00-7.00)$.

Similarly, an exposure to occupational brain trauma was associated with approximately the same amount of risk $(\mathrm{OR}=2.00,95 \% \mathrm{CI}=1.00$ 6.00). Moreover, a history of more than 20 years of work in the operational fields was associated with a 5 times increase in the risk of dementia $(\mathrm{OR}=5.00,95 \% \mathrm{CI}=$ 3.00-8.00). Further details are presented in the table 5 .

5. Results of multivariate logistic regression model for dementia

\begin{tabular}{|l|l|c|c|c|}
\hline \multirow{1}{*}{$\begin{array}{l}\text { Occupationa } \\
\text { I risk factors }\end{array}$} & Adjusted Odds & 95\% CI & p-value \\
\cline { 2 - 5 } & Fossil fuels & 1.00 & $(0.00-4.00)$ & $<.001$ \\
\cline { 2 - 5 } & Solvents & 1.00 & $(0.00-4.00)$ & $<.001$ \\
\cline { 2 - 5 } & $\begin{array}{l}\text { Electro-magnetic } \\
\text { fields }\end{array}$ & .00 & $(0.00-1.012)$ & $<.001$ \\
\cline { 2 - 5 } & Air pollution & 2.00 & $(1.00-7.00)$ & .017 \\
\cline { 2 - 5 } & Noise pollution & .00 & $(0.00-1.00)$ & $<.001$ \\
\cline { 2 - 5 } & $\begin{array}{l}\text { A combination of the } \\
\text { Occupational risk } \\
\text { factors }\end{array}$ & .00 & $(0.00-3.00)$ & $<.001$ \\
\cline { 2 - 5 } & Head trauma & & & .010 \\
\hline
\end{tabular}




\begin{tabular}{|l|l|c|c|c|}
\hline \multicolumn{2}{|l}{$\begin{array}{l}\text { Less than 20 years of } \\
\text { work in the } \\
\text { operational fields }\end{array}$} & 1.00 & $(0.00-4.00)$ & $<.001$ \\
\cline { 2 - 5 } & $\begin{array}{l}\text { 20 years or more of } \\
\text { work in the } \\
\text { operational fields }\end{array}$ & 5.00 & $(3.00-8.00)$ & $<.001$ \\
\hline
\end{tabular}

\section{Discussion}

Previous studies have related dementia to occupational risk factors, but to our knowledge, until now, no domestic study have been done to assess the relationship between them.

In the present study, we found that a long-term exposure to air pollution was significantly associated with an increase in the risk of dementia in the older adults. This finding is consistent with the results of the other studies, which show that exposures to air pollutants can increase the risk of cognitive problems (24). However, studies on dementia and air pollutants are rare and if not, until now have not been able to explain the relationship fully between dementia and air pollutants. Some studies have focused on the individual constituents of air pollution such as ozone and particulate matter. For example, Animal studies suggested that particulate matter may cause brain inflammation which is the product of the accumulation of $\mathrm{Ab} 42$, which in turn causes the aftermath dysfunction of, cerebrovascular damage, neural degeneration and dementia (24). Likewise, some other animal studies relate ozone-caused oxidative stress to the deficiency of brain repair mechanisms, which leads to memory loss and dementia (25).

In line with the previous studies, our study showed that exposure to head injury increased the risk of dementia. The unadjusted risk was even higher. The relationship between head injury and dementia has long been an interesting subject for the researcher for many years. In addition, while the clinical trials report no association between them, epidemiological studies constantly suggest head injury as a risk factor for dementia (26-28). Nevertheless, what seems to be consistent in all the epidemiological 
studies including ours is that there is at least a weak association between head injury and dementia. A systematic review and Meta-analyze by Vanesa et al. reported a weak association between head injury and (5). Similarly, another Systematic Review and Meta-Analysis by Yanjun Li et al. emphasized on head injury as a risk factor for dementia (28). A possible mechanism suggested by is that recurring head injury leads to chronic traumatic, which in turn leads to dementia (29). Since we compared all dementia cases with non-demented controls for head trauma exposure, the observed relationship puts forward the notion that the relationship between head trauma and dementia is not specific to a single subgroup of dementia, rather, head trauma is a risk factor for all dementias which was also proposed by Salib et al in their study(27).

In the present study, more than 20 years of work in the operational fields was related with a 5times increase in the risk of dementia. If we assume the length of exposure tantamount to the number of years then this relationship would be reasonable. In his case-control study, Amy showed that an increased exposure to solvents had increased the risk of
Alzheimer's disease. However, when the intensity level of each exposed job was multiplied by the number of years on the job the increase in risk with increasing dose was no longer significant (30). Given the relationship between exposure time and the risk of dementia, it seems logical that in long term, the so-called occupational risk factors are accumulated in the central nerves system that in turn is supported by literature (31).

\section{References}

DIAGNOSTIC CRITERIA FOR DEMENTIA, Dementia Australia (C2012, $\quad$ Reviewed 2018. https://www.dementia.org.au/files/helps heets/Helpsheet.

International AsD. World Alzheimer report 2010: the global economic impact of dementia: Alzheimer's Disease International; 2010.

Gauthier S, Albert M, Fox N, Goedert M, Kivipelto M, Mestre-Ferrandiz J, et al. Why has therapy development for dementia failed in the last two decades? 
Alzheimer's \& Dementia. 2016; 12(1):60-4.

Sosa-Ortiz AL, Acosta-Castillo I, Prince MJ. Epidemiology of dementias and Alzheimer's disease. Archives of medical research. 2012; 43(8):600-8.

Bellou V, Belbasis L, Tzoulaki I, Middleton LT, Ioannidis JP, Evangelou E. Systematic evaluation of the associations between environmental risk factors and dementia: An umbrella review of systematic reviews and metaanalyses. Alzheimer's \& Dementia. 2017; 13(4):406-18.

Norton S, Matthews FE, Barnes DE, Yaffe K, Brayne C. Potential for primary prevention of Alzheimer's disease: an analysis of population-based data. The Lancet Neurology. 2014; 13(8):7889426.

Ott A, Stolk R, Van Harskamp F, Pols H, Hofman A, Breteler M. Diabetes mellitus and the risk of dementia The Rotterdam Study. Neurology. 1999; 53(9):1937-.
Peila R, Rodriguez BL, Launer LJ. Type

2 diabetes, APOE gene, and the risk for dementia and related pathologies The Honolulu-Asia Aging Study. Diabetes. 2002; 51(4):1256-62.

Skoog I, Nilsson L, Persson G, Lernfelt B, Landahl S, Palmertz B, et al. 15-year longitudinal study of blood pressure and dementia. The Lancet. 1996; 347(9009):1141-5.

Swiger K, Manalac R, Blumenthal R, editors. Statin use reduces risk of dementia. Mayo Clin Proc; 2013.

Mitchell AJ. Depression as a risk factor for later dementia: a robust relationship? Age and ageing. 2005;34(3):207-9.

Janicki SC, Schupf N. Hormonal influences on cognition and risk for Alzheimer's disease. Current neurology and neuroscience reports. 2010;10(5):359-66.

Seshadri S, Beiser A, Selhub J, Jacques PF, Rosenberg IH, D'Agostino RB, et al. Plasma homocysteine as a risk factor for dementia and Alzheimer's disease. New 
England Journal of Medicine. 2002;346(7):476-83.

Gustafson D, Rothenberg E, Blennow K, Steen B, Skoog I. An 18-year follow-up of overweight and risk of Alzheimer disease. Archives of internal medicine. 2003; 163(13):1524-8.

Riggs JE. The influence of smoking on the risk of Alzheimer's disease. Neurology. 2000;54(3):777--a.

Breteler M. Vascular risk factors for Alzheimer's disease:: An epidemiologic perspective. Neurobiology of aging. 2000;21(2):153-60.

Dong-Mei Zhang, MD, Jian-Xin Ye, MD, Jun-Shan Mu, MD,

Xiao-Ping Cui, PhD. Efficacy of Vit B Supplementation on Cognition in Elderly Patients with Cognitive-Related Diseases :A Systematic review and Meta-Analysis. Journal of Geriatric Psychiatry and Neurology.2017. Vol. 30(1)50-59.

https://journals.sagepub.com/doi/abs/10. 1177/0891988716673466.
Ramos MI, Allen LH, Mungas DM, Jagust WJ, Haan MN, Green R, et al. Low folate status is associated with impaired cognitive function and dementia in the Sacramento Area Latino Study on Aging-. The American journal of clinical nutrition. 2005;82(6):134652.

Sommer I, Griebler U, Kien C, Auer S, Klerings I, Hammer R, et al. Vitamin D deficiency as a risk factor for dementia: a systematic review and meta-analysis. BMC geriatrics. 2017;17(1):16.

Sharp ES, Gatz M. The relationship between education and dementia an updated systematic review. Alzheimer disease and associated disorders. 2011;25(4):289.

Bertram L, Lill CM, Tanzi RE. The genetics of Alzheimer disease: back to the future. Neuron. 2010;68(2):270-81.

Julie Hugo, Mary Ganguli . Dementia and Cognitive Impairment: Epidemiology, Diagnosis, and Treatment. Clin Geriatr Med. 2014 Aug; 30(3): 421-442. 
Seyedian M., Falah M., Nourouzian M., Nejat S., Delavar A., Ghasemzadeh H.A. Validity of the Farsi version of MINIMENTAL STATE EXAMINATION. JOURNAL OF MEDICAL COUNCIL OF I.R.I. WINTER 2008 , Volume 25 , Number 4 ; Page(s) 408 To 414.

Wu Y-C, Lin Y-C, Yu H-L, Chen J-H, Chen T-F, Sun Y, et al. Association between air pollutants and dementia risk in the elderly. Alzheimer's \& Dementia: Diagnosis, Assessment \& Disease Monitoring. 2015;1(2):220-8.

Hernandez-Zimbron L, Rivas-Arancibia S. Oxidative stress caused by ozone exposure induces $\beta$-amyloid $1-42$ overproduction and mitochondrial accumulation by activating the amyloidogenic pathway. Neuroscience. 2015;304:340-8.

Plassman BL, Havlik R, Steffens D, Helms M, Newman T, Drosdick D, et al. Documented head injury in early adulthood and risk of Alzheimer's disease and other dementias. Neurology. 2000;55(8):1158-66.
Salib E, HILLIER V. Head injury and the risk of Alzheimer's disease: a case control study. International journal of geriatric psychiatry. 1997;12(3):363-8.

Li Y, Li Y, Li X, Zhang S, Zhao J, Zhu $\mathrm{X}$, et al. Head injury as a risk factor for dementia and Alzheimer's disease: a systematic review and meta-analysis of 32 observational studies. PloS one. 2017;12(1):e0169650.

Mez J, Daneshvar DH, Kiernan PT, Abdolmohammadi B, Alvarez VE, Huber BR, et al. Clinicopathological evaluation of chronic traumatic encephalopathy in players of American football. Jama. 2017;318(4):360-70.

Graves AB, Rosner D, Echeverria D, Mortimer JA, Larson EB. Occupational exposures to solvents and aluminium and estimated risk of Alzheimer's disease. Occupational and environmental medicine. 1998;55(9):627-33.

Block ML, Calderón-Garcidueñas L. Air pollution: mechanisms of neuroinflammation and CNS disease. Trends in neurosciences. 2009;32(9):506-16 